\title{
Multidrug resistance-associated protein 4 is a determinant of arsenite resistance
}

\author{
BO YUAN ${ }^{1-3}$, YUTA YOSHINO ${ }^{2}$, HISAYO FUKUSHIMA ${ }^{1}$, SVETLANA MARKOVA ${ }^{1}$, \\ NORIO TAKAGI ${ }^{3}$, HIROO TOYODA ${ }^{2}$ and DEANNA L. KROETZ ${ }^{1}$ \\ ${ }^{1}$ Department of Bioengineering and Therapeutic Sciences, University of California San Francisco, San Francisco, \\ CA 94143, USA; Departments of ${ }^{2}$ Clinical Molecular Genetics and ${ }^{3}$ Applied Biochemistry, School of Pharmacy, \\ Tokyo University of Pharmacy and Life Sciences, Hachioji, Tokyo 192-0392, Japan
}

Received July 13, 2015; Accepted August 19, 2015

DOI: $10.3892 /$ or.2015.4343

\begin{abstract}
Although arsenic trioxide (arsenite, $A s^{\mathrm{III}}$ ) has shown a remarkable efficacy in the treatment of acute promyelocytic leukemia patients, multidrug resistance is still a major concern for its clinical use. Multidrug resistance-associated protein 4 (MRP4), which belongs to the ATP-binding cassette (ABC) superfamily of transporters, is localized to the basolateral membrane of hepatocytes and the apical membrane of renal proximal tubule cells. Due to its characteristic localization, MRP4 is proposed as a candidate in the elimination of arsenic and may contribute to resistance to $\mathrm{As}^{\mathrm{III}}$. To test this hypothesis, stable HEK293 cells overexpressing MRP4 or MRP2 were used to establish the role of these two transporters in $\mathrm{As}^{\mathrm{III}}$ resistance. The $\mathrm{IC}_{50}$ values of $\mathrm{As}^{\mathrm{III}}$ in MRP4 cells were approximately 6-fold higher than those in MRP2 cells, supporting an important role for MRP4 in resistance to $\mathrm{As}^{\mathrm{III}}$. The capacity of MRP4 to confer resistance to $\mathrm{As}^{\mathrm{III}}$ was further confirmed by a dramatic decrease in the $\mathrm{IC}_{50}$ values with the addition of MK571, an MRP4 inhibitor, and cyclosporine A, a well-known broad-spectrum inhibitor of ABC transporters. Surprisingly, the sensitivity of the MRP2 cells to As ${ }^{\mathrm{III}}$ was similar to that of the parent cells, although insufficient formation of glutathione and/or Se conjugated arsenic compounds in the MRP2 cells might limit transport. Given that MRP4 is a major contributor to arsenic resistance in vitro, further investigation into the
\end{abstract}

Correspondence to: Dr Bo Yuan, Department of Applied Biochemistry, School of Pharmacy, Tokyo University of Pharmacy and Life Sciences, 1432-1 Horinouchi, Hachioji, Tokyo 192-0392, Japan

E-mail: yuanbo@toyaku.ac.jp

Professor Deanna L. Kroetz, Department of Bioengineering and Therapeutic Sciences, University of California San Francisco, 1550 4th Street, RH584E Box 2911, San Francisco, CA 94143, USA

E-mail: deanna.kroetz@ucsf.edu

Key words: arsenite, cytotoxicity, multidrug resistance-associated protein 4, MRP2, multidrug resistance correlation between MRP4 expression and treatment outcome of leukemia patients treated with arsenic-based regimens is warranted.

\section{Introduction}

Arsenic and arsenic-containing compounds are widely distributed in the environment and exist in organic and inorganic forms. Although a well-known poison, arsenic has been used medicinally for over 2,000 years (1). In particular, administration of arsenic trioxide (arsenite, $\mathrm{As}^{\mathrm{III}}$ ), an arsenic derivative, has demonstrated a remarkable efficacy in the treatment of relapsed and refractory acute promyelocytic leukemia (APL) (1-4). Detailed pharmacokinetic studies of As ${ }^{\mathrm{III}}$ in APL patients have been carried out to optimize treatment $(3,5-8)$. Both inorganic arsenic and methylated arsenic metabolites accumulate in red blood cells during repeated administration of As ${ }^{\mathrm{III}}$ to APL patients (7). Arsenic metabolites are also detected in cerebrospinal fluid (6) at concentrations of arsenic necessary for induction of differentiation $(4,9)$. Recent data from our laboratory demonstrated that the profiles of arsenic species in peripheral blood (PB) plasma were very similar to those of bone marrow (BM) plasma, suggesting that the profiles of PB plasma could be predictive biomarkers for the treatment outcome of APL patients (8). These findings on the pharmacokinetics of As ${ }^{\mathrm{III}}$ in APL patients provide new insight into clinical applications of $\mathrm{As}^{\mathrm{III}}$, and may contribute to designing better therapeutic protocols (1).

Multidrug resistance is a major concern for the clinical use of anticancer drugs. ATP-binding cassette (ABC) transporters contribute to drug resistance via ATP-dependent drug efflux $(1,10)$. Multidrug resistance-associated proteins 1 and 2 (MRP1/2), and multidrug resistance protein 1 (MDR1; also known as P-glycoprotein, P-gp) have been implicated in the efflux of arsenic, and may contribute to resistance to arsenic therapy $(1,11,12)$. Furthermore, we recently demonstrated the MRP2 and aquaporin-9 (AQP9), a member of the aquaporin superfamily, involvement in arsenic uptake (1,13-15), contributing to the differential sensitivity of primary human-derived normal cells to arsenite (14,16-18). Although these previous findings provide fundamental knowledge for understanding the cellular handling and elimination pathways of arsenic in 
cancer cells as well as normal cells, more studies are required to provide detailed information on the efficacy and safety of arsenic for clinical use.

MRP4 transports antiviral agents such as the nucleoside/nucleotide analogs azidothymidine (AZT), adefovir [9-(2-phosphonylmethoxyethyl) adenine or PMEA] and tenofovir (TFV) (19-21), and anticancer drugs such as camptothecins and methotrexate (22-24). Of note, recent studies have demonstrated that hematopoietic progenitor cell differentiation affects expression and function of MRP4, and that MRP4 has a relevant role in tumor growth and apoptosis and in the eradication of leukemic stem cells, suggesting MRP4 as a new potential therapeutic target for acute myeloid leukemia $(25,26)$. It is noteworthy that MRP4 is localized to the basolateral membrane of hepatocytes and the apical membrane of renal proximal tubule cells, distinguishing itself from other members of the MRP family (21). Considering the localization of MRP4, biomethylation of arsenic primarily in liver and elimination of arsenic by the kidney (1), MRP4 is an ideal candidate for the elimination of arsenic and may contribute to resistance to $\mathrm{As}^{\mathrm{III}}$. Only recently have studies been reported regarding the role of MRP4 in arsenic resistance $(27,28)$. In the present study, stable human embryonic kidney epithelial (HEK)293 cells overexpressing MRP4 and MRP2 were created and used to investigate the cytotoxicity of $\mathrm{As}^{\mathrm{III}}$ against both MRP overexpressing cells and reference cells transfected with an empty vector, in order to clarify whether MRP4 cells have the capacity to confer drug resistance to $\mathrm{As}^{\mathrm{III}}$.

\section{Materials and methods}

Reagents. Sodium arsenite (As $\left.{ }^{\mathrm{III}}\right)$ was purchased from Tri Chemical Laboratories (Yamanashi, Japan). Cyclosporin A (CsA), a broad-spectrum inhibitor of ABC transporters, was kindly provided by Professor Toshihiko Hirano, Department of Clinical Pharmacology, School of Pharmacy, Tokyo University of Pharmacy and Life Sciences.3-[[3-[2-(7-chloroquinolin-2-yl) vinyl]phenyl]-(2-dimethylcarbamoylethylsulfanyl)methylsulfanyl] propionic acid (MK571), an inhibitor of MRP4, was purchased from Merck (Darmstadt, Germany).

Construction of stable HEK293 cell lines expressing human $M R P 2$ or MRP4 cDNA. Human ABCC2 or ABCC4 cDNA was subcloned into the pcDNA5/FRT vector (Invitrogen, Carlsbad, CA, USA) as described previously $(19,20)$. Briefly, HEK293 Flp-In cells were seeded at $5 \times 10^{5}$ cells/well in 6 -well plates in Dulbecco's modified Eagle's medium (DMEM) with $10 \%$ fetal bovine serum (FBS) without antibiotics. After $24 \mathrm{~h}$ of cultivation, $0.4 \mu \mathrm{g}$ MRP2 or MRP4 plasmid was transfected into HEK293 Flp-In cells using Lipofectamine 2000 (Invitrogen) according to the manufacturer's protocol. Empty pcDNA/FRT vector was transfected as a negative control (empty vector cells). DMEM fresh media were added at $6 \mathrm{~h}$ post-transfection. The selection of stable cell clones expressing MRP2 or MRP4 reference plasmid was started in $75 \mu \mathrm{g} / \mathrm{ml}$ hygromycin (Invitrogen) the following day. Media were changed every 2-3 days, and selection of stable transfectants generally took 10-14 days. HEK293 cells stably expressing MRP2 reference (MRP2 cells) or MRP4 reference (MRP4 cells) and empty vector cells were cultured in DMEM supplemented with $10 \%$
FBS, $100 \mathrm{U} / \mathrm{ml}$ of penicillin and $100 \mu \mathrm{g} / \mathrm{ml}$ of streptomycin at $37^{\circ} \mathrm{C}$ in a humidified atmosphere $\left(5 \% \mathrm{CO}_{2}\right.$ in air $)$.

MRP2 protein isolation and western blot analysis. Proteins were isolated using PARIS ${ }^{\mathrm{TM}}$ kit (Ambion Life Technologies, Foster City, CA, USA) according to the manufacturer's protocol. Proteins (30 $\mu \mathrm{g} / \mathrm{lane})$ were separated on $4-15 \%$ Tris-HCl Criterion gels (Bio-Rad, Hercules, CA, USA) by SDS-PAGE at $80 \mathrm{~V}$ and then transferred onto nitrocellulose membranes at $250 \mathrm{~mA}$ for $2 \mathrm{~h}$. Membranes were blocked in $2 \%$ skim milk for $1 \mathrm{~h}$ at room temperature and incubated overnight at $4^{\circ} \mathrm{C}$ with anti-MRP2 antibody (M2-III-6) at 1:250 dilution (Thermo Fisher Scientific, Rockford, IL, USA) or anti-GAPDH antibody (ab9483) at 1:100,000 dilution (Abcam, Cambridge, MA, USA). The following day, membranes were washed three times with phosphate-buffered saline (PBS) and then incubated with IRdye 800CW goat anti-mouse fluorescent secondary antibody (Li-COR, Lincoln, NE, USA) at 1:10,000 dilution. Membranes were washed with PBS and visualized on an Odyssey ${ }^{\circledR}$ Sa Infrared Imaging system (Li-COR).

Evaluation of MRP2 membrane expression by immunocytochemistry. Empty vector and MRP2 reference cells were seeded at $2.5 \times 10^{4} /$ chamber on 4 -chamber slides $24 \mathrm{~h}$ prior to staining. The following day cells were washed with cold PBS two times and permeabilized with cold acetone for $10 \mathrm{~min}$ on ice. An equal volume of $8 \%$ paraformaldehyde was added directly to the cells and incubated for $10 \mathrm{~min}$ at room temperature. Cells were washed with PBS two times and blocked with $2 \mathrm{mg} / \mathrm{ml} \mathrm{BSA}$ solution for $30 \mathrm{~min}$ at room temperature. Primary anti-MRP2 (M2-III-6) antibody was added to BSA solution to the final dilution of 1:20. After three washes with PBS, the slides were incubated with a fluorescently conjugated secondary antibody (Alexa Fluor ${ }^{\circledR} 488$; Thermo Fisher Scientific) for $1 \mathrm{~h}$ at room temperature protected from light. DAPI (Thermo Fisher Scientific) stain at 1:3,000 dilution was added $20 \mathrm{~min}$ before the end of incubation. After three washes with PBS, images were mounted and then captured using a Retiga CCD-cooled camera and associated QCapture Pro software (QImaging, Surrey, BC, Canada).

Functional assays of MRP2 cells. Evaluation of MRP2 transport activity was performed using a carboxyfluorescein (CF) fluorescent dye retention assay. CF was applied to cells in its di-acetate (CFDA) form (Sigma-Aldrich, St. Louis, MO, USA) which is non fluorescent and highly lipophilic; it freely enters the cells through passive diffusion. Once inside the cell the acetate groups of CFDA are cleaved by esterases yielding fluorescent $\mathrm{CF}$, which has low permeability characteristics and is a substrate for ABC efflux transporters, including MRP2 (29). Briefly, empty vector and MRP2 overexpressing cells were trypsinized, washed with warm PBS and re-suspended at a cell density of $1 \times 10^{6}$ cells $/ \mathrm{ml}$ in fresh DMEM without FBS. Cells were then incubated for $30 \mathrm{~min}$ at $37^{\circ} \mathrm{C}$ with $10 \mu \mathrm{M}$ of CFDA. Following accumulation, cells were pelleted, washed twice with warm PBS, re-suspended in DMEM media supplemented with $10 \% \mathrm{FBS}$ and allowed to efflux for $30 \mathrm{~min}$ at $37^{\circ} \mathrm{C}$. Following efflux, cells were pelleted, washed twice with ice-cold PBS and then re-suspended in ice-cold PBS supplemented with $10 \%$ FBS for analysis. Retention of CF was determined by 
A

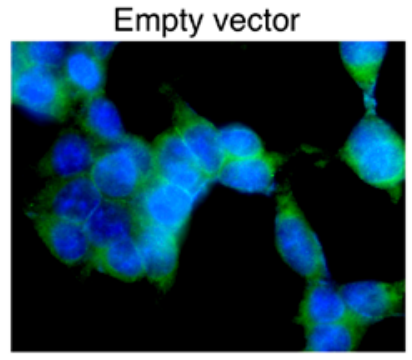

B

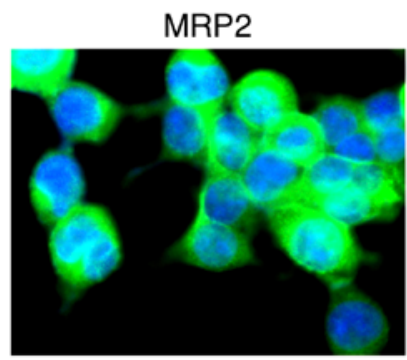

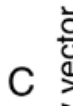

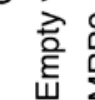

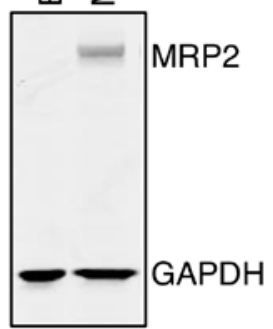

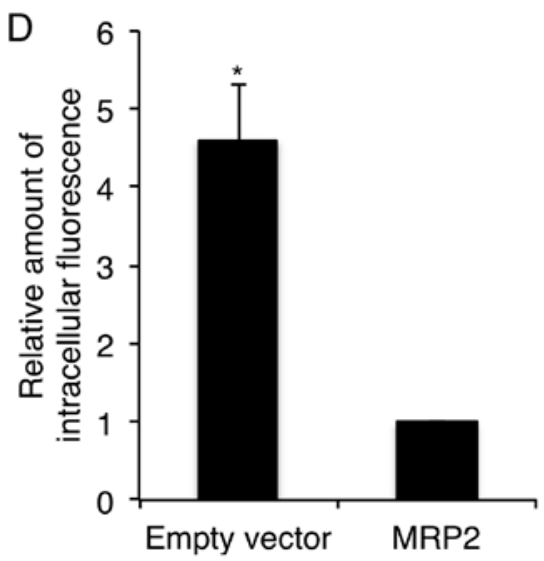

Figure 1. MRP2 expression and transporter activity in MRP2 stable cell line. Immunocytochemistry (A and B) and western blotting (C) for the expression of MRP2 protein, and CF fluorescent dye retention assay (D) for MRP2 activity were carried out as described under Materials and methods. Results are shown as the means \pm SD from four independent experiments. For each experiment, data were normalized to empty vector cells. Significant differences were observed between MRP2 and empty vector cells $\left({ }^{*} \mathrm{P}<0.05\right)$.

measuring fluorescence using flow cytometry performed on a BD FACSCalibur (BD Biosciences, Mississauga, ON, Canada). Briefly, 10,000 cell events were collected for each sample. Cells were co-stained with propidium iodide (PI; Thermo Fisher Scientific) to exclude non-viable cells from further analysis. CF fluorescence was measured in FL-1 channel (excitation wavelength $488 \mathrm{~nm}$ and emission wavelength $530 \mathrm{~nm}$ ), and PI fluorescence was measured in FL-3 channel (excitation wavelength $488 \mathrm{~nm}$ and emission wavelength $600 \mathrm{~nm}$ ). Each experiment was repeated four times. Data were normalized to empty vector transfected cells and a t-test was used on normalized data to test for differences in MRP2 overexpressing cells and reference cells.

Functional assays of MRP4 cells. Transport assays for MRP4 were carried out using two reported MRP4 substrates [adenine-8- ${ }^{3} \mathrm{H}$-tenofovir disoproxil (TFV) $(3.8 \mathrm{Ci} / \mathrm{mmol}$, $98.1 \%$ purity); ${ }^{3} \mathrm{H}-9-(2$-phosphonylmethoxyethyl)-adenine (PMEA)] (Moravek Biochemicals, Brea, CA, USA) as described previously $(19,20,30)$. Briefly, MRP4 and empty vector cells were seeded at $2.5 \times 10^{5}$ cells/well in triplicate in poly-D-lysine-coated 24-well plates (BD Biosciences, San Jose, CA, USA). After preincubation for $24 \mathrm{~h}$, cells were incubated with $1 \mu \mathrm{M}$ TFV or $100 \mathrm{nM}$ PMEA in glucose-free DMEM supplemented with $10 \mu \mathrm{M} \mathrm{NaN}_{3}$ and $10 \mu \mathrm{M} 2$-deoxy-D-glucose, respectively, for $2 \mathrm{~h}$ at $37^{\circ} \mathrm{C}$. After accumulation, cells were washed with ice-cold PBS and supplemented with complete
DMEM. Supernatant fractions were collected at 0,30 and $90 \mathrm{~min}$, and cells were washed and lysed with $800 \mu \mathrm{l} /$ well of an aqueous solution of $10 \%$ sodium dodecyl sulfate and $1 \mathrm{~N}$ $\mathrm{NaOH}$. Supernatants were added to Ecolite scintillation fluid (MP Biomedicals, Santa Ana, CA, USA) and extracellular amounts of TFV and PMEA were analyzed by scintillation counting. The remaining cell lysate was used to determine the protein concentration with a $\mathrm{BCA}^{\mathrm{TM}}$ Protein Assay kit (Pierce Biotechnology, Rockford, IL, USA); TFV and PMEA levels were normalized to protein concentrations.

Cell viability assay. The cytotoxicity of $\mathrm{As}^{\mathrm{III}}$ to MRP4, MRP2 and empty vector cells was investigated by XTT dye-reduction assays according to the method previously described with slight modifications $(14,31)$. Briefly, the cells were seeded in 96-well plates (Iwaki, Tokyo, Japan) at a density of $5 \times 10^{3}$ cells/well in $0.1 \mathrm{ml}$ complete DMEM and cultivated for $24 \mathrm{~h}$. Cultures in triplicate were treated with various concentrations of $\mathrm{As}^{\mathrm{III}}$ in the presence or absence of transporter inhibitors at the concentrations indicated. Cells were pre-incubated with transporter inhibitors at the indicated concentrations for $30 \mathrm{~min}$. After treatment with $\mathrm{As}^{\mathrm{III}}$ for an additional 48 h, 2,3-bis(2-methoxy-4-nitro-5-sulfophenyl)5-[(phenylamino)carbonyl]-2H-tetrazolium hydroxide (XTT; Sigma, MD, USA) and phenazine methosulfate (Wako Pure Chemical Industries, Osaka, Japan) were added into each well at final concentrations of $0.2 \mathrm{mg} / \mathrm{ml}$ and $1 \mathrm{mM}$, respectively. 

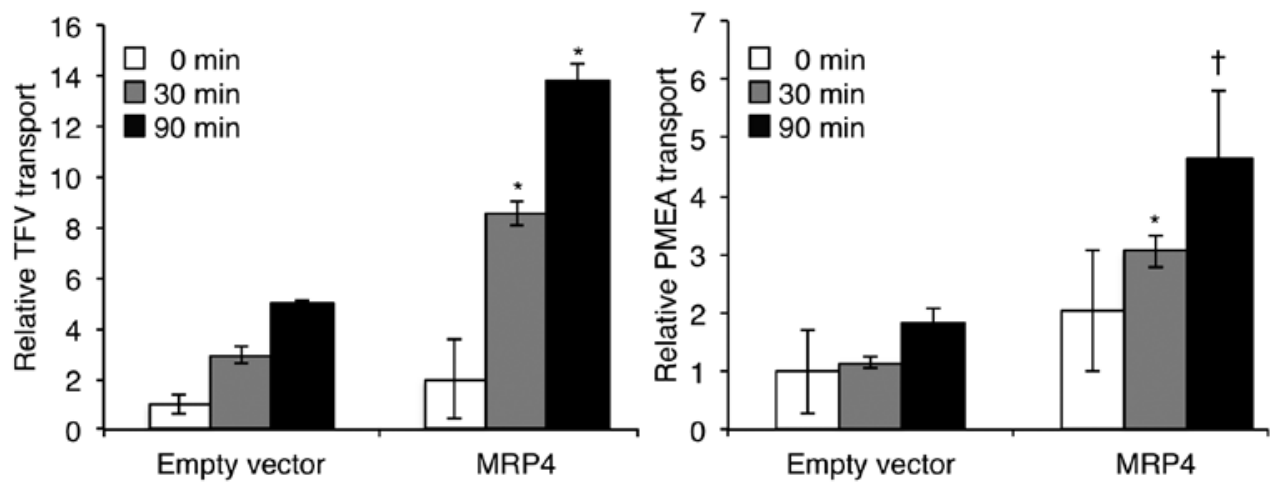

Figure 2. Transporter activity in MRP4 stable cell line. Transport assays for MRP4 activity were carried out using two reported MRP4 substrates (TFV and PMEA) as described under Materials and methods. Data are shown as the means \pm SD from three independent experiments. For each experiment, data were normalized to empty vector cells. Significant differences were observed between MRP4 and empty vector cells at each time-point $\left({ }^{*} \mathrm{P}<0.01,{ }^{\dagger} \mathrm{P}<0.05\right)$.

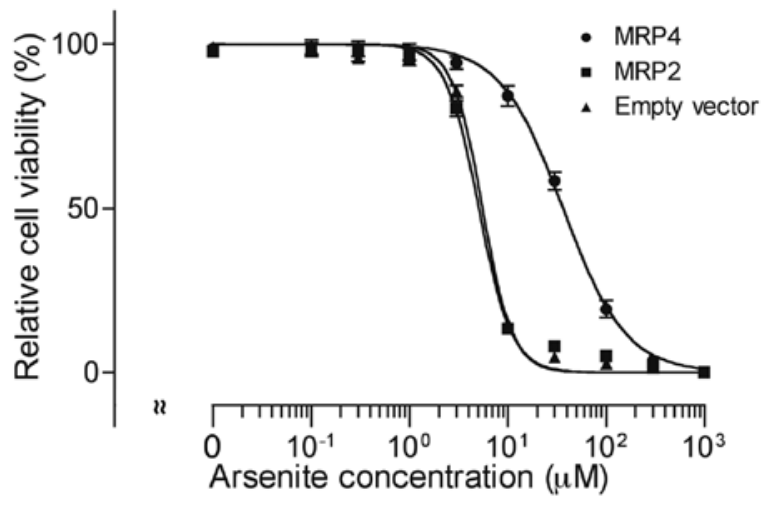

Figure 3. As ${ }^{\mathrm{III}}$-induced cytotoxicity in MRP4 and MRP2 overexpressing cells. After treatment with $0-1,000 \mu \mathrm{M}$ of $\mathrm{As}^{\mathrm{III}}$ for $48 \mathrm{~h}$, cell viability was quantified with an XTT assay as described in Materials and methods. Data are shown as means \pm SD from more than five independent experiments. The $\mathrm{IC}_{50}$ value for $\mathrm{As}^{\mathrm{III}}$ in MRP4 cells was significantly greater than the corresponding value in empty vector cells $(\mathrm{P}<0.01)$.

After incubation at $37^{\circ} \mathrm{C}$ for $4 \mathrm{~h}$, the plates were mixed, and the absorbance at $450 \mathrm{~nm}$ was measured with a microplate reader (Safire, Tecan, Switzerland). The relative cell viability was expressed as the ratio of the absorbance of each treatment group against those of the corresponding untreated control group. Data are shown as means \pm SD from more than five independent experiments. The $\mathrm{IC}_{50}$ values of $\mathrm{As}^{\mathrm{III}}$ for all three cell types were calculated using GraphPad Prism ${ }^{\circledR} 5$ software.

Statistical analysis. Data were analyzed using Student's t-test and ANOVA with a Dunnett's post test method. A p-value $<0.05$ was considered as statistically significant.

\section{Results}

Confirmation of MRP2 expression and transporter activity in the MRP2 stable cell line. Protein expression of MRP2 was confirmed using immunocytochemistry and western blotting. As shown in Fig. 1, MRP2 cells had significantly higher levels of membrane (Fig. 1A and B) and total (Fig. 1C) MRP2 expression compared to empty vector transfected cells. Functional activity of MRP2 was confirmed in MRP2 reference cells using a CF retention assay. As shown in Fig. 1D, retention of CF in MRP2 overexpressing cells was 4.5-fold lower than that in empty vector cells, indirectly confirming high efflux of fluorescent dye from MRP2 overexpressing cells and, therefore, providing strong evidence for MRP2 functional activity.

Confirmation of transporter activity in the MRP4 stable cell line. Accumulation of TFV or PMEA in the supernatant fractions of each cell type was assessed for confirmation of MRP4 function. As shown in Fig. 2, the accumulation of TFV or PMEA in the supernatant of MRP4 cells increased with time, and was much higher than that of empty vector cells. Compared to empty vector cells, an approximately 3-fold and 2.7-fold increase in the efflux of TFV and PMEA, respectively, was observed in the MRP4 cells at the 30 and 90 min timepoints (Fig. 2), indicating functional MRP4.

As ${ }^{I I I}$-induced cytotoxicity in MRP4 and MRP2 cells. After treatment with $0,0.1,0.3,1,3,10,30,100,300$ and $1,000 \mu \mathrm{M}$ of As ${ }^{\mathrm{III}}$ for $48 \mathrm{~h}$, cell viability was investigated by XTT assay. A significant dose-dependent decrease in cell viability was observed in all three cell types (Fig. 3). As ${ }^{\mathrm{III}}$ exhibited much lower cytotoxicity in MRP4 cells in comparison with MRP2 and empty vector cells. The $\mathrm{IC}_{50}$ values of AsIII were 36.6 \pm 8.1 , $5.1 \pm 0.3$ and $5.5 \pm 0.3 \mu \mathrm{M}$ in MRP4, MRP2 and empty vector cells (MRP4 vs. empty vector, $\mathrm{P}<0.01 ; \mathrm{MRP} 2$ vs. empty vector, $\mathrm{P}>0.05)$, respectively.

Effect of MK571 on As ${ }^{I I}$-induced cytotoxicity in MRP4 and empty vector cells. Both MRP4 and empty vector cells were exposed to various concentrations of $\mathrm{As}^{\mathrm{III}}(0-1,000 \mu \mathrm{M})$ in the presence or absence of 10 or $25 \mu \mathrm{M}$ MK571 for $48 \mathrm{~h}$, followed by the assessment of cell viability. The $\mathrm{IC}_{50}$ value of $\mathrm{As}^{\mathrm{III}}$ in MRP4 cells decreased significantly from $28.2 \pm 3.3$ to $11.2 \pm 3.3$ and $6.3 \pm 1.0 \mu \mathrm{M}$ by the addition of 10 and $25 \mu \mathrm{M}$ MK571 (MRP4 without MK571 vs. MRP4 with 10 or $25 \mu \mathrm{M}$ MK571, $\mathrm{P}<0.01$ ), respectively (Fig. 4A). Interestingly, the addition of MK571 also slightly enhanced $\mathrm{As}^{\mathrm{III}}$-induced cytotoxicity in empty vector cells, with the $\mathrm{IC}_{50}$ value of $\mathrm{As}{ }^{\mathrm{III}}$ decreasing from $4.8 \pm 0.8$ to $3.3 \pm 0.4$ and $2.5 \pm 0.2 \mu \mathrm{M}$ by the addition of 10 and $25 \mu \mathrm{M}$ MK571 (empty vector cells without MK571 vs. empty vector cells with 10 or $25 \mu \mathrm{M}$ MK571, $\mathrm{P}<0.05)$, respectively (Fig. 4B). 

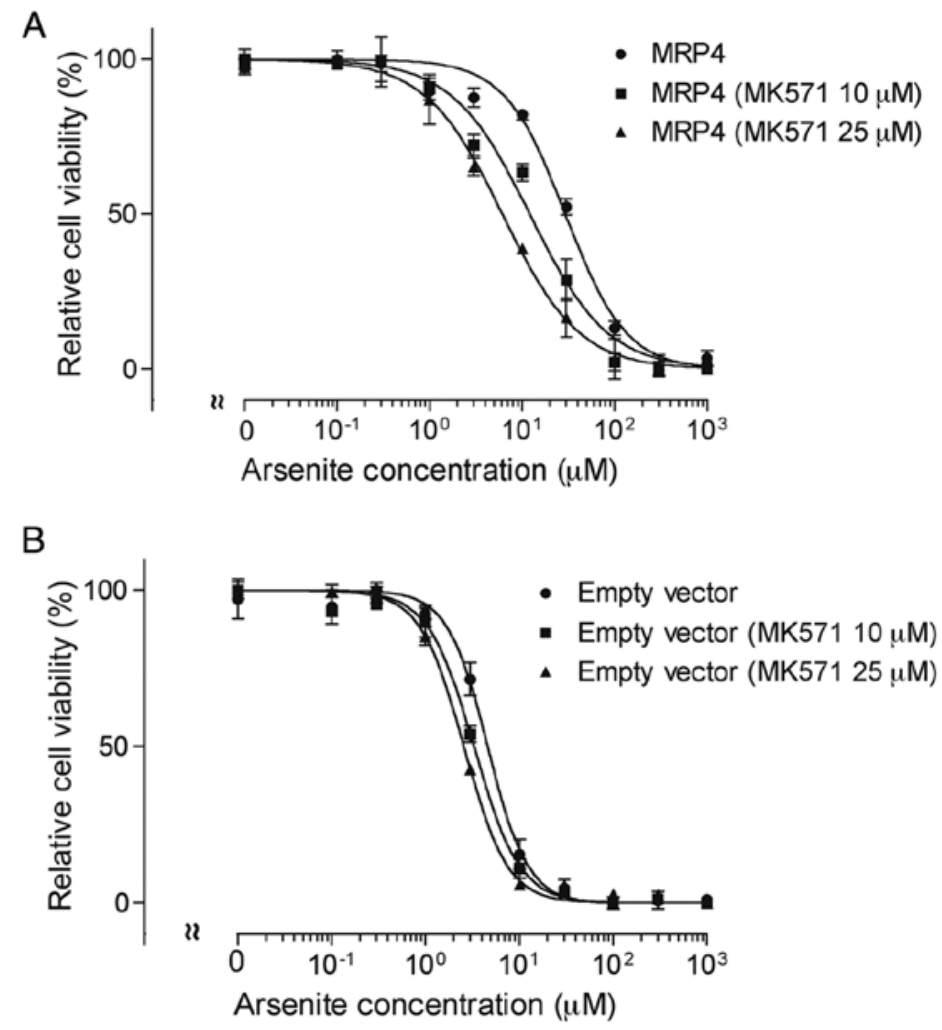

Figure 4. Effect of MK571 on As ${ }^{\mathrm{III}}$-induced cytotoxicity in MRP4 overexpressing cells. MRP4 (A) and empty (B) vector cells were exposed to various concentrations of $\mathrm{As}^{\mathrm{III}}(0-1,000 \mu \mathrm{M})$ in the presence or absence of 10 or $25 \mu \mathrm{M}$ MK571 for $48 \mathrm{~h}$, followed by the assessment of cell viability. Data are shown as means $\pm \mathrm{SD}$ from more than five independent experiments. The $\mathrm{IC}_{50}$ value for $\mathrm{As}^{\mathrm{III}}$ in MRP4 and empty vector cells decreased significantly in the presence of MK571 ( $\mathrm{P}<0.01$ for MRP4 and $\mathrm{P}<0.05$ for empty vector).

Effect of CsA on As ${ }^{I I I}$-induced cytotoxicity in MRP4 and empty vector cells. Both MRP4 and empty vector cells were exposed to various concentrations of AsIII $(0-1,000 \mu \mathrm{M})$ in the presence or absence of 1 or $3 \mu \mathrm{M}$ CsA for $48 \mathrm{~h}$, followed by the assessment of cell viability. In comparison to MK571, CsA, a broad-spectrum inhibitor of ABC transporters, more potently inhibited MRP4 and increased $\mathrm{As}^{\mathrm{III}}{ }_{\text {-induced }}$ cytotoxicity (Fig. 5A). The $\mathrm{IC}_{50}$ value of $\mathrm{As}^{\mathrm{III}}$ in MRP4 cells decreased $\geq 90 \%$ after the addition of 1 and $3 \mu \mathrm{M}$ CsA, respectively (Fig. 5A). There was some increase in As ${ }^{\mathrm{III}}$ cytotoxicity as well in empty vector cells $(5.3 \pm 0.2$ vs $3.1 \pm 0.6$ and $2.3 \pm 0.2 \mu \mathrm{M})$ (empty vector cells without CsA vs. empty vector cells with 1 or $3 \mu \mathrm{M} \mathrm{CsA}, \mathrm{P}<0.05$ ) (Fig. 5B).

\section{Discussion}

MRP2 and MRP4 overexpressing cells were used in the current study to evaluate the contribution of these $\mathrm{ABC}$ efflux transporters to $\mathrm{As}{ }^{\mathrm{III}}$ cytotoxicity. A 6-fold difference in $\mathrm{IC}_{50}$ values of $\mathrm{As}^{\mathrm{III}}$ between these cells and a significant reduction of the $\mathrm{IC}_{50}$ value in MRP4 cells provide strong support that MRP4 is a major mediator of As ${ }^{\mathrm{III}}$ efflux from cells and plays a major role in $\mathrm{As}{ }^{\mathrm{III}}$ resistance. MRP2 has been demonstrated to be involved in the efflux of arsenic, conferring resistance to $\mathrm{As}^{\mathrm{III}}$ in other experimental systems $(12,32,33)$. Wild-type and MRP2-deficient Wistar (TR) rats have been used to show that MRP2 is responsible for the biliary excretion of arsenic triglutathione $\left[\mathrm{As}(\mathrm{GS})_{3}\right]$ and monomethyl arsenic diglutathione $\left[\mathrm{CH}_{3} \mathrm{As}(\mathrm{GS})_{2}\right]$ (33). These in vivo findings are supported by cellular transport assays demonstrating that $\mathrm{As}(\mathrm{GS})_{3}$ is also a substrate for human MRP2 (12). A recent in vitro study using MRP2-enriched membrane vesicles demonstrated that MRP2 transports seleno-bis(S-glutathionyl) arsinium ion $\left[\left((\mathrm{GS})_{2} \mathrm{AsSe}\right)^{-}\right]$(32). These previous findings suggest that glutathione and/or the essential trace element selenium (Se) are required for the excretion and detoxification of arsenic. In contrast, using MRP2 overexpressing cells in the present study, there was no evidence that MRP2 plays a critical role in $\mathrm{As}^{\mathrm{III}}$ transport and cytotoxicity. These conflicting results might reflect low levels of glutathione and/or Se conjugation in MRP2 overexpressing HEK293 cells, although more detailed analysis of the molecular events such as the amount of glutathione and its conjugated arsenic compounds is required to confirm this hypothesis.

Inhibition studies further support the role of MRP4 to confer resistance to $\mathrm{As}^{\mathrm{III}}$. MK571, an MRP4 inhibitor (21), was used to demonstrate that MRP4 confers resistance to a series of camptothecin analogs, including irinotecan and SN-38 $(23,24)$. Consistent with these previous studies, the addition of MK571 significantly potentiated $\mathrm{As}^{\mathrm{III}}$-triggered cytotoxicity in the MRP4 cells in a dose-dependent manner. CsA, a well-known broad-spectrum inhibitor of ABC transporters, increased $\mathrm{As}^{\mathrm{III}}$-triggered cytotoxicity to a greater degree than MK571, supporting a role for multiple ABC transporters in $\mathrm{As}^{\mathrm{III}}$ cytotoxicity. Collectively, our experimental results implicate MRP4 in resistance to $\mathrm{As}^{\mathrm{III}}$. Considering that multidrug resistance-reversing activity of CsA has been reported in phase II studies with myeloma and acute leukemia, 
A

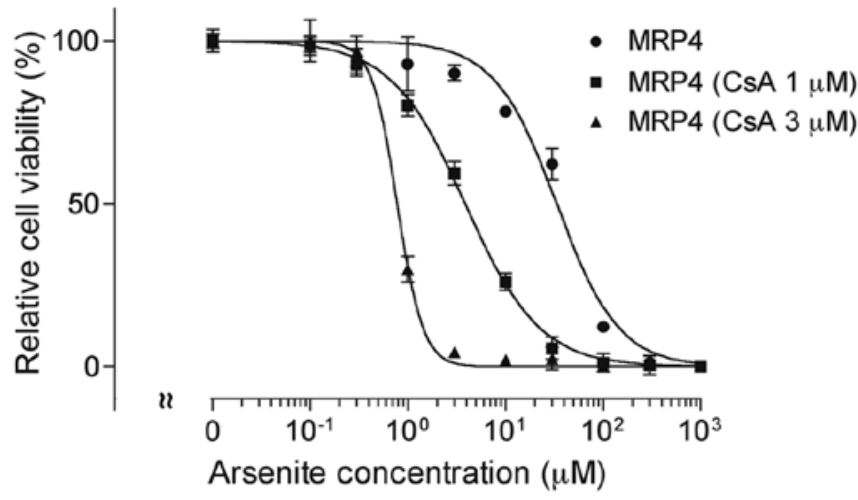

B

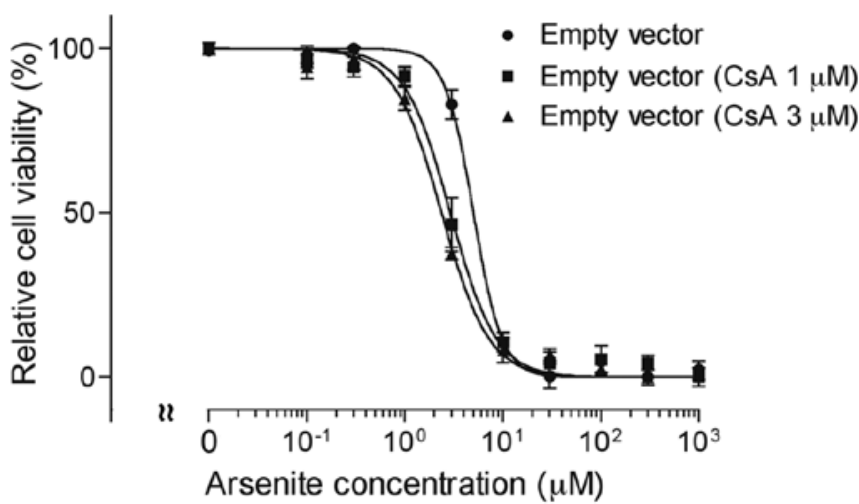

Figure 5. Effect of CsA on As ${ }^{\mathrm{III}}$-induced cytotoxicity in MRP4 overexpressing cells. MRP4 (A) and empty vector (B) cells were exposed to various concentrations of $\mathrm{As}^{\mathrm{III}}(0-1,000 \mu \mathrm{M})$ in the presence or absence of 1 or $3 \mu \mathrm{M}$ CsA for $48 \mathrm{~h}$, followed by the assessment of cell viability. Data are shown as means $\pm \mathrm{SD}$ from more than five independent experiments. The $\mathrm{IC}_{50}$ value for $\mathrm{As}^{\mathrm{III}}$ in MRP4 and empty vector cells decreased significantly in the presence of CsA $(\mathrm{P}<0.01$ for MRP4 and $\mathrm{P}<0.05$ for empty vector).

increased recognition of drug-drug interactions is necessary for optimal treatment of patients with arsenic-based regimens.

Our results are not completely in agreement with other studies of arsenic resistance. Increased resistance was not detected in MRP4-transfected NIH3T3 cells after exposure to sodium meta-arsenite for $72 \mathrm{~h}$ (28). Furthermore, a recent report demonstrated that after treatment with increasing concentrations of inorganic and methylated species of arsenic for $72 \mathrm{~h}, \mathrm{MRP} 4$-transfected HEK293 cells conferred resistance to arsenate and methylated species of arsenic except for arsenite (27). Plausible explanations for the differences between our findings and previous reports are differences in cell lines, arsenite reagent, treatment durations and stable versus transient overexpression systems.

MRP4 has been proposed to contribute to arsenic elimination due to its characteristic localization in both the basolateral membrane of hepatocytes and the apical membrane of renal proximal tubule cells $(21,27)$. Based on transport studies using MRP4-enriched membrane vesicles, the diglutathione conjugate of MMA ${ }^{\mathrm{III}}$, monomethylarsenic diglutathione [MMA(GS) $)_{2}$, and $\mathrm{DMA}^{\mathrm{V}}$ are transported by MRP4 (27). It is noteworthy that MRP4 has been reported to regulate intracellular cyclic adenosine monophosphate (cAMP) levels, an endogenous substrate identified for MRP4 (21), in AML cell lines and contribute to cell proliferation and differentiation (34). Moreover, Copsel et al recently reported that MRP4 blockade strongly reduced tumor growth by inducing cell cycle arrest and apoptosis in U937 xenografted mice, and further demonstrated that increased cAMP levels and MRP4 inhibition resulted in leukemic stem cell differentiation (25). Of note, a rapid increase in intracellular cAMP has been linked to all-trans retinoic acid (ATRA)-induced differentiation in the human APL cell line NB4 and in fresh APL cells (35). More importantly, cAMP facilitates the degradation of As ${ }^{\mathrm{III}}$-mediated fusion protein promyelocytic leukemia (PML)-retinoic acid receptor $\alpha(\mathrm{RAR} \alpha)$, a fusion gene generated by the $\mathrm{t}(15 ; 17)$ translocation in APL and though to play a central role in the initiation of leukemogenesis $(1,4,36)$. These previous findings raised the possibility that MRP4 would be a novel promising target in APL therapy. The expression of MRP4 increased in CD34 ${ }^{+}$cells differentiated toward megakaryocytes with thrombopoietin, and a similar increase was also observed in a megakaryoblastic cell line (M-07e) derived from a patient with megakaryoblastic leukemia, when differentiated toward megakaryocytes (26). However, the expression of MRP4 decreased in $\mathrm{CD} 34^{+}$cells differentiated toward monocytes with G-CSF, suggesting a relevant role of MRP4 in hematopoietic progenitor cell differentiation (26). Therefore, considering the expression status of MRPs, including MRP4, is important for providing meaningful clinical benefits for patients with different types of hematological disorders.

It is noteworthy that the MRP4 gene is highly polymorphic, and numerous nonsynonymous single-nucleotide polymorphisms (SNPs) have been identified (21). Functional studies have shown that although there was no evidence for a complete loss of function allele, two variants (G187W and G487E) show 
a significantly reduced function compared to reference MRP4 as evidenced by higher intracellular accumulation of ATZ and PMEA, two antiviral substrates for MRP4 (19). Although no disease has so far been directly linked to altered MRP4 activity, evaluating the functional effects of high frequency variants on the disposition of arsenic has important implications for hematologic malignancy patients treated with arsenic-based regimens.

In conclusion, our results demonstrated the capacity of MRP4 to confer resistance to $\mathrm{As}^{\mathrm{III}}$ as evidenced by cell survival assays when treated with $\mathrm{As}^{\mathrm{III}}$ in the presence or absence of its two differential inhibitors. Given that MRP4 is widely distributed in the body, and plays a pivotal role in the drug concentrations achieved clinically, monitoring its expression levels may have important implications for predicting not only clinical efficacy but also side effects of arsenite and its metabolites. Obviously, clinical data are required to support the role of MRP4 in drug disposition and efficacy. Based on our findings and previous studies showing that MRP4 could be a major contributor to arsenic resistance, further investigation into the correlation between the expression level of MRP4 and treatment outcome of leukemia patients treated with arsenic-based regimens is warranted.

\section{References}

1. Yuan B, Yoshino Y, Kaise T and Toyoda H: Application of arsenic trioxide therapy for patients with leukemia. In: Biological Chemistry of Arsenic, Antimony and Bismuth. Sun H (ed). John Wiley and Sons, Ltd., Chichester, pp263-292, 2011.

2. Cohen MH, Hirschfeld S, Flamm Honig S, Ibrahim A, Johnson JR, O'Leary JJ, White RM, Williams GA and Pazdur R: Drug approval summaries: Arsenic trioxide, tamoxifen citrate, anastrazole, paclitaxel, bexarotene. Oncologist 6: 4-11, 2001.

3. Shen ZX, Chen GQ, Ni JH, Li XS, Xiong SM, Qiu QY, Zhu J, Tang W, Sun GL, Yang KQ, et al: Use of arsenic trioxide $\left(\mathrm{As}_{2} \mathrm{O}_{3}\right)$ in the treatment of acute promyelocytic leukemia (APL): II. Clinical efficacy and pharmacokinetics in relapsed patients. Blood 89: 3354-3360, 1997.

4. Soignet SL, Maslak P, Wang ZG, Jhanwar S, Calleja E, Dardashti LJ, Corso D, DeBlasio A, Gabrilove J, Scheinberg DA, et al: Complete remission after treatment of acute promyelocytic leukemia with arsenic trioxide. N Engl J Med 339: 1341-1348, 1998 .

5. Fujisawa S, Ohno R, Shigeno K, Sahara N, Nakamura S, Naito K, Kobayashi M, Shinjo K, Takeshita A, Suzuki Y, et al: Pharmacokinetics of arsenic species in Japanese patients with relapsed or refractory acute promyelocytic leukemia treated with arsenic trioxide. Cancer Chemother Pharmacol 59: 485-493, 2007.

6. Kiguchi T, Yoshino Y, Yuan B, Yoshizawa S, Kitahara T, Akahane D, Gotoh M, Kaise T, Toyoda H and Ohyashiki K: Speciation of arsenic trioxide penetrates into cerebrospinal fluid in patients with acute promyelocytic leukemia. Leuk Res 34: 403-405, 2010

7. Yoshino Y, Yuan B, Miyashita SI, Iriyama N, Horikoshi A, Shikino O, Toyoda $\mathrm{H}$ and Kaise T: Speciation of arsenic trioxide metabolites in blood cells and plasma of a patient with acute promyelocytic leukemia. Anal Bioanal Chem 393: 689-697, 2009.

8. Iriyama N, Yoshino Y, Yuan B, Horikoshi A, Hirabayashi Y, Hatta Y, Toyoda H and Takeuchi J: Speciation of arsenic trioxide metabolites in peripheral blood and bone marrow from an acute promyelocytic leukemia patient. J Hematol Oncol 5: 1, 2012.

9. Chen GQ, Shi XG, Tang W, Xiong SM, Zhu J, Cai X, Han ZG, Ni JH, Shi GY, Jia PM, et al: Use of arsenic trioxide $\left(\mathrm{As}_{2} \mathrm{O}_{3}\right)$ in the treatment of acute promyelocytic leukemia (APL): $\mathrm{I}_{2} \mathrm{As}_{2} \mathrm{O}_{3}$ exerts dose-dependent dual effects on APL cells. Blood 89: 3345-3353, 1997.

10. Morjani $\mathrm{H}$ and Madoulet $\mathrm{C}$ : Immunosuppressors as multidrug resistance reversal agents. Methods Mol Biol 596: 433-446, 2010.
11. Lee TC, Ho IC, Lu WJ and Huang JD: Enhanced expression of multidrug resistance-associated protein 2 and reduced expression of aquaglyceroporin 3 in an arsenic-resistant human cell line. J Biol Chem 281: 18401-18407, 2006.

12. Leslie EM, Haimeur A and Waalkes MP: Arsenic transport by the human multidrug resistance protein 1 (MRP1/ABCC1). Evidence that a tri-glutathione conjugate is required. J Biol Chem 279: 32700-32708, 2004.

13. Bhattacharjee H, Carbrey J, Rosen BP and Mukhopadhyay R: Drug uptake and pharmacological modulation of drug sensitivity in leukemia by AQP9. Biochem Biophys Res Commun 322: 836-841, 2004.

14. Yoshino Y, Yuan B, Kaise T, Takeichi M, Tanaka S, Hirano T, Kroetz DL and Toyoda H: Contribution of aquaporin 9 and multidrug resistance-associated protein 2 to differential sensitivity to arsenite between primary cultured chorion and amnion cells prepared from human fetal membranes. Toxicol Appl Pharmacol 257: 198-208, 2011.

15. Iriyama N, Yuan B, Yoshino Y, Hatta Y, Horikoshi A, Aizawa S, Takeuchi J and Toyoda H: Aquaporin 9, a promising predictor for the cytocidal effects of arsenic trioxide in acute promyelocytic leukemia cell lines and primary blasts. Oncol Rep 29: 2362-2368, 2013.

16. Yuan B, Ohyama K, Bessho T and Toyoda H: Contribution of inducible nitric oxide synthase and cyclooxygenase-2 to apoptosis induction in smooth chorion trophoblast cells of human fetal membrane tissues. Biochem Biophys Res Commun 341: 822-827, 2006.

17. Yuan B, Ohyama K, Bessho T, Uchide $\mathrm{N}$ and Toyoda H: Imbalance between ROS production and elimination results in apoptosis induction in primary smooth chorion trophoblast cells prepared from human fetal membrane tissues. Life Sci 82: 623-630, 2008.

18. Yuan B, Ohyama K, Takeichi M and Toyoda H: Direct contribution of inducible nitric oxide synthase expression to apoptosis induction in primary smooth chorion trophoblast cells of human fetal membrane tissues. Int J Biochem Cell Biol 41: 1062-1069, 2009.

19. Abla N, Chinn LW, Nakamura T, Liu L, Huang CC, Johns SJ, Kawamoto M, Stryke D, Taylor TR, Ferrin TE, et al: The human multidrug resistance protein 4 (MRP4, ABCC4): Functional analysis of a highly polymorphic gene. J Pharmacol Exp Ther 325: 859-868, 2008.

20. Kelly L, Fukushima H, Karchin R, Gow JM, Chinn LW, Pieper U, Segal MR, Kroetz DL and Sali A: Functional hot spots in human ATP-binding cassette transporter nucleotide binding domains. Protein Sci 19: 2110-2121, 2010.

21. Russel FG, Koenderink JB and Masereeuw R: Multidrug resistance protein 4 (MRP4/ABCC4): A versatile efflux transporter for drugs and signalling molecules. Trends Pharmacol Sci 29: 200-207, 2008.

22. Chen ZS, Lee K, Walther S, Raftogianis RB, Kuwano M, Zeng H and Kruh GD: Analysis of methotrexate and folate transport by multidrug resistance protein 4 (ABCC4): MRP4 is a component of the methotrexate efflux system. Cancer Res 62: 3144-3150, 2002.

23. Tian Q, Zhang J, Chan SY, Tan TM, Duan W, Huang M, Zhu YZ, Chan E, Yu Q, Nie YQ, et al: Topotecan is a substrate for multidrug resistance associated protein 4. Curr Drug Metab 7: $105-118,2006$.

24. Tian Q, Zhang J, Tan TM, Chan E, Duan W, Chan SY, Boelsterli UA, Ho PC, Yang H, Bian JS, et al: Human multidrug resistance associated protein 4 confers resistance to camptothecins. Pharm Res 22: 1837-1853, 2005.

25. Copsel S, Bruzzone A, May M, Beyrath J, Wargon V, Cany J, Russel FG, Shayo C and Davio C: Multidrug resistance protein 4/ ATP binding cassette transporter 4: A new potential therapeutic target for acute myeloid leukemia. Oncotarget 5: 9308-9321, 2014.

26. Oevermann L, Scheitz J, Starke K, Köck K, Kiefer T, Dölken G, Niessen J, Greinacher A, Siegmund W, Zygmunt M, et al: Hematopoietic stem cell differentiation affects expression and function of MRP4 (ABCC4), a transport protein for signaling molecules and drugs. Int J Cancer 124: 2303-2311, 2009.

27. Banerjee M, Carew MW, Roggenbeck BA, Whitlock BD, Naranmandura H, Le XC and Leslie EM: A novel pathway for arsenic elimination: Human multidrug resistance protein 4 (MRP4/ABCC4) mediates cellular export of dimethylarsinic acid (DMAV) and the diglutathione conjugate of monomethylarsonous acid (MMAIII). Mol Pharmacol 86: 168-179, 2014. 
28. Lee K, Klein-Szanto AJ and Kruh GD: Analysis of the MRP4 drug resistance profile in transfected NIH3T3 cells. J Natl Cancer Inst 92: 1934-1940, 2000.

29. Lee G and Piquette-Miller M: Influence of IL-6 on MDR and MRP-mediated multidrug resistance in human hepatoma cells. Can J Physiol Pharmacol 79: 876-884, 2001.

30. Schuetz JD, Connelly MC, Sun D, Paibir SG, Flynn PM, Srinivas RV, Kumar A and Fridland A: MRP4: A previously unidentified factor in resistance to nucleoside-based antiviral drugs. Nat Med 5: 1048-1051, 1999.

31. Kikuchi H, Yuan B, Yuhara E, Imai M, Furutani R, Fukushima S, Hazama S, Hirobe C, Ohyama K, Takagi N, et al: Involvement of histone $\mathrm{H} 3$ phosphorylation via the activation of p38 MAPK pathway and intracellular redox status in cytotoxicity of HL-60 cells induced by Vitex agnus-castus fruit extract. Int J Oncol 45: 843-852, 2014.

32. Carew MW and Leslie EM: Selenium-dependent and -independent transport of arsenic by the human multidrug resistance protein 2 (MRP2/ABCC2): Implications for the mutual detoxification of arsenic and selenium. Carcinogenesis 31: 1450-1455, 2010 .
33. Kala SV, Neely MW, Kala G, Prater CI, Atwood DW, Rice JS and Lieberman MW: The MRP2/cMOAT transporter and arsenic-glutathione complex formation are required for biliary excretion of arsenic. J Biol Chem 275: 33404-33408, 2000.

34. Copsel S, Garcia C, Diez F, Vermeulem M, Baldi A, Bianciotti LG, Russel FG, Shayo C and Davio C: Multidrug resistance protein 4 (MRP4/ABCC4) regulates cAMP cellular levels and controls human leukemia cell proliferation and differentiation. J Biol Chem 286: 6979-6988, 2011.

35. Zhao Q, Tao J, Zhu Q, Jia PM, Dou AX, Li X, Cheng F, Waxman S, Chen GQ, Chen SJ, et al: Rapid induction of cAMP/PKA pathway during retinoic acid-induced acute promyelocytic leukemia cell differentiation. Leukemia 18: 285-292, 2004.

36. Zhu Q, Zhang JW, Zhu HQ, Shen YL, Flexor M, Jia PM, Yu Y, Cai X, Waxman S, Lanotte M, et al: Synergic effects of arsenic trioxide and cAMP during acute promyelocytic leukemia cell maturation subtends a novel signaling cross-talk. Blood 99: 1014-1022, 2002. 